\title{
Role of Negative-Pressure Wound Therapy in Deep Sternal Wound Infection After Open Heart Surgery
}

\section{Açık Kalp Cerrahisinden Sonra Derin Sternum Yara Infeksiyonunda Negatif Basınçlı Yara Tedavisinin Rolü}

Cemalettin Aydın ${ }^{1}$, Halil Başel ${ }^{1}$, ibrahim Kara ${ }^{2}$, Yasin $\mathrm{Ay}^{1}$, Murat Songur ${ }^{3}$, Mehmet Yanartaş ${ }^{4}$, Süleyman Yazıcı ${ }^{5}$

${ }^{1}$ Department of Cardiovascular Surgery, Faculty of Medicine, Bezmialem Vakif University, Istanbul, Turkey

${ }^{1}$ Bezmiâlem Vakıf Üniversitesi Tıp Fakültesi, Kalp ve Damar Cerrahisi Anabilim Dalı, İstanbul, Türkiye

2 Department of Cardiovascular Surgery, Emsey Hospital, Istanbul, Turkey

${ }^{2}$ Emsey Hastanesi, Kalp ve Damar Cerrahisi Bölümü, İstanbul, Türkiye

${ }^{3}$ Department of Cardiovascular Surgery, High Specialization Training and Research Hospital, Ankara, Turkey

${ }^{3}$ Türkiye Yüksek Ihtisas Eğitim ve Araştırma Hastanesi, Kalp ve Damar Cerrahisi Kliniği, Ankara, Türkiye

${ }^{4}$ Department of Cardiovascular Surgery, Kosuyolu Heart Center, Kartal, Istanbul, Turkey

${ }^{4}$ Kartal Koşuyolu Yüksek ihtisas Eğitim ve Araştırma Hastanesi, Kalp ve Damar Cerrahisi Kliniği, Kartal, Istanbul, Türkiye

${ }^{5}$ Department of Cardiovascular Surgery, Faculty of Medicine, Dicle University, Diyarbakir, Turkey

${ }^{5}$ Dicle Üniversitesi Tıp Fakültesi, Kalp ve Damar Cerrahisi Anabilim Dalı, Diyarbakır, Türkiye

\section{ABSTRACT}

Introduction: Mediastinitis is a devastating complication in open heart surgery. The most common treatments after debridement are rewiring with antibiotic irrigation. Vacuum assisted closure therapy is a recently introduced technique that promotes the healing of difficult wounds, including post-sternotomy mediastinitis.

Patients and Methods: Forty one patients with deep sternal wound infection were divided into two groups based on the treatment method used. Twenty two patients with post-cardio to my deep sternal wound infection were treated primarily by vacuum assisted closure method (group A) and 19 patients with deep sternal wound infection who received closed mediastinal irrigation were treated with antibiotics (group B) between January 2006 and January 2010.

Results: The two groups were compared. Three patients died during treatment in group $B$. The median healing time was significantly shorter in group $A$ (mean, $13.5 \pm 3.2$ days) compared to 18 days (mean, $21.2 \pm 16.4$ days) in group $B(p<0.001)$. Deep sternal wound infection showed no recurrences after the vacuum treatment, while 7 (24\%) patients in group $B$ suffered recurrences. Hospital stay was significantly shorter in group $A$ (median, 30.5 days; mean, $32.2 \pm 11.3$ days vs. median, 45 days; mean, $49.2 \pm 19.3$ days) $(p=0.001)$.

Conclusion: A significantly shorter healing time was confirmed with vacuum assisted closure. Hospital stay remained significantly shorter in group A (35 vs. 46 days).

Key Words: Negative-pressure wound therapy; mediastinitis; sternum; surgical wound infection; wound healing.

Received: 18.12 .2012 • Accepted: 19.03.2013 


\section{ÖZET}

Giriş: Mediyastinit kalp cerrahisinde yıkıcı bir komplikasyondur. En sık tedavi şekli debridman sonrası yaranın tekrar kapatılması ve mediyastenin antibiyotikle irrigasyonudur. Vakum yardımlı kapalı tedavi yöntemi son zamanlarda ortaya çıkmış bir tedavi tekniği olup, sternotomi sonrası mediyastinitler gibi zor yaralarda iyileşmeyi kolaylaştırmaktadır.

Hastalar ve Yöntem: Ocak 2006-Ocak 2010 tarihleri arasında derin sternal yara gelişen 41 hasta kullanılan tedavi yöntemine göre iki gruba ayrıldı. Mediyastinitli 22 hasta devamlı vakum destekli kapalı yöntemle tedavi edildi (grup A). On dokuz mediyastinitli hastaya antibiyotikle kapalı mediyastinal irrigasyon tedavisi uygulandı (grup B).

Bulgular: Iki grup karşılaştırıldı. Grup B'den üç hasta tedavi sırasında kaybedildi. Ortalama iyileşme süresi grup A'da (13.5 \pm 3.2 gün), grup B'ye (21.2 \pm 16.4 gün) göre belirgin olarak daha kısa idi $(p<0.001)$. Vakum tedavisi sonrası hastalarda nüks görülmezken, grup B'de 7 (\%24) hastada infeksiyon tekrarlamıştır. Hastanede kalım süresi grup A'da ortalama 30.5 (32.2 \pm 11.3$)$ gün, grup B'de ise ortalama 45 (49.2 \pm 19.3$)$ gün olup, grup A'da belirgin olarak daha kısa idi $(p=0.001)$.

Sonuç: Kapalı vakum sisteminde iyileşme süresi belirgin olarak kısa bulunmuştur. Hastanede kalım süresi grup A'da önemli oranda kısadır.

Anahtar Kelimeler: Negatif basınçlı yara tedavisi; mediyastinit; sternum; cerrahi yara infeksiyonu; yara iyileşmesi.

Geliş Tarihi: 18.12.2012 • Kabul Tarihi: 19.03.2013

\section{INTRODUCTION}

Mediastinitis is a devastating complication in open heart surgery. Major advancements were achieved in the treatment of wound dehiscence with sternotomy in 1963 when Shumacker et al. ${ }^{(1)}$ closed chest catheter introduce closedchest catheter antibiotic irrigation after sternal debridement and again in 1980 when closure with muscle flaps was introduced by Jurkiewicz et al. ${ }^{(2)}$ vacuum assisted closure (VAC) therapy is a recently-introduced technique that promotes the healing of difficult wounds, including post-sternotomy mediastinitis ${ }^{(3)}$. The suction force created by VAC therapy enables the drainage of excessive fluid and debris, which leads to the removal of wound edema, reduction in bacterial counts, enhanced blood flow, and granulation tissue formation $^{(4)}$. Deep sternal wound infection complicates $1 \%$ to $8 \%$ of cardiac interventions. The related mortality, despite improved antibiotic therapy and asepsis in perioperative care, is still high, ranging from $5 \%$ to $47 \%$. However, effective treatment for mediastinitis, including MRSA mediastinitis, remains controversial ${ }^{(5)}$. Shumacker et al. described a technique of wound debridement, primary sternal closure, and closed mediastinal catheter irrigation in $1963^{(6)}$. The use of iodine solution or adilute antibiotic for mediastinal irrigation led to a marked reduction in mortality, and this therapy has been the treatment of choice for over 3 decades, although mortality and morbidity rates have remained high ${ }^{(7)}$. A new era in the treatment of post-sternotomy mediastinitis began in 1999 when Obdeijn et al. ${ }^{(8)}$ described the use of the VAC for post-sternotomy mediastinitis. The aim of this study was to compare the outcomes of treatment with VAC and the traditional therapy of closed-chest irrigation.

\section{PATIENTS and METHODS}

3227 patients underwent cardiac surgery through complete median sternotomy at our clinic between January 2000 and January 2010. Deep sternal wound infection occurred in 41 patients, who were divided into two groups based on the treatment methodused: group $A$ included 22 patients primarily treated by VAC, and group $B$ included 19 patients who received closed mediastinal irrigation with antibiotic solution. Groups A and B were comparable in terms of preoperative risk factors (age, New York Heart Association class, ejection fraction, pre-operative myocardial infarction, EuroSCORE). Group A patients were treated according to our most recent strategy: all cases of wound discharge and even minimal sternal instability underwent early surgical reopening of the wound, removal of sternal stitches, and extensive scraping of the infected tissues. Subcutaneous tissue, mediastinal fluid, and sternal bone debris samples were collected for microbiology testing. Abundant saline irrigation was followed by hemostasis. Three layers of paraffin gauze dressing were placed on the heart, and sterile polyurethane foam dressing was trimmed to fit between the sternal edges. Often, a second piece of foam was placed over the first to completely cover the subcutaneous tissues of the wound. A transparent adhesive drape was attached to the foam and around a 6-8 $\mathrm{cm}$ margin of the wound. A drainage tube was placed under the drape to allow drainage and vacuum application. The vacuum source was a $\mathrm{KCl} V A C$ system pump unit ( $\mathrm{KCl}$ International, San Antonio, TX, USA). All patients were extubated immediately after the end of the procedure and returned to the ward. They were treated with a con- 
tinuous negative pressure of $-90 \mathrm{mmHg}$. The polyurethane foam was changed three times weekly under aseptic conditions, without anesthesia. The necrotic tissue was gently cleaned during the procedure where necessary. The VAC treatment was terminated after not less than 10 days upon achievement of lack of fever, normalization of leukocytes, decreased C-reactive protein, and a macroscopically infection free wound. Surgical reconstruction of the wound was performed in all patients, using a pectoralis muscle flap. Parenteral antibiotic therapy was conducted following microbiological tests during the treatment.

In group B, deep sternal wound infection was treated according to a precise flowchart: all patients with wound discharge and even minimal sternal instability underwent wound debridement and mediastinal irrigation with povidone-iodine solution (PVI) on an emergency basis (stage 1). Patients were taken to the operating room and the wound was re-opened. All sternal wires and fascial or subcutaneous sutures were removed, samples of mediastinal fluids were taken for culture, and the pericardial sac was washed with antibiotic and PVI. A drain for mediastinal irrigation was placed as well as 2 tubes for drainage: one in the pericardium and one in the anterior mediastinum. If the pleural space was opened, an additional drain was inserted just above the diaphragm. Extensive debridement of the sternum and superficial layers was carried out until fresh bleeding was noted from the edge of the wound. The sternum was not approximated and only skin and fullthickness subcutaneous layers were closed using nonabsorbable interrupted stitches. Mediastinal irrigation was performed with alternating $5 \% \mathrm{PVI}$ and a $0.1 \%$ vancomycin solution at $100 \mathrm{~mL}$ every 6 hours. Intravenous antibiotic therapy was continued throughout the mediastinal irrigation stage based on microbiology test results. On the $7^{\text {th }}$ post-operative day, the infusion was withdrawn and swabs for culture were taken from the drains. If the cultures were sterile, wound healing was satisfactory, and fever and leukocytosis had disappeared, the drains were removed and the patient was discharged. If wound drainage and/or bacterial growth from cultures were observed, mediastinal irrigation was restarted and continued for another seven days before the drains were removed. When infection recurred (seven cases), the patients entered stage 2 of the treatment protocol. The sternotomy wound was re-opened and repeat debridement was performed. The mediastinum and the surface of the wound were flushed with PVI and packed with antibiotic-soaked gauze. The following day, treatment with granulated sugar was started. The wound was washed once a day with oxygen peroxide and $5 \% \mathrm{PVI}$, and filled with granulated sugar four times a day until the wound healed or the patient underwent pectoralis muscle flap reconstruction. Antibiotics were continued, according to in vitro susceptibility test results, until the wound healed. Samples from the wound were taken everyday, and blood cultures were performed when body temperature rose above $38^{\circ} \mathrm{C}$. The full blood count was checked daily, and blood glucose four times a day. When cultures from the wound showed no pathogen growth and the white blood cell count fell with in the normal range, the patient and relatives were trained in the dressing technique with granulated sugar. Three patients who showed delayed healing of the wound and wanted earlier hospital discharge entered stage 3 of the protocol: they were referred to a plastic surgeon, and pectoralis muscle flap reconstruction was performed.

\section{Statistical Analysis}

Hospital stay and time between deep sternal wound infection treatment initiation and wound healing were compared between the two groups, using the Mann-Whitney $\mathrm{U}$ test.

\section{RESULTS}

Pre-operative and per-operative data were given Table 1. Hospital stay was significantly shorter in group A (median, 30.5 days; mean, $32.2 \pm 11.3$ days vs. median, 45 days; mean, $49.2 \pm 19.3$ days) than in group $B$ (median, 45 days; mean, $49.2 \pm 19.3$ days) $(p=0.001)$. No patients in group $A$ died, while three patients in group $B$ died during deep sternal wound infection treatment $(p=0.09)$. The median healing time was 13.5 days in group $A$ (mean, $11.9 \pm$ 3.1 days) and 18 days (mean, $28.2 \pm 15.2$ days) in group $B$ $(p<0.001)$. No patients in group A presented with recurrent deep sternal wound infection, while $7(36.8 \%)$ in group B suffered a recurrence and were treated successfully with VAC therapy $(p=0.002)$ (Table 2$)$.

\section{DISCUSSION}

The treatment of deep sternal wound infection is still a challenge for cardiothoracic surgeons, and it has evolved over the decades. A therapeutic approach based on prolonged antibiotic therapy alone was associated with unacceptable mortality and morbidity rates, and was abandoned $^{(5)}$. Closed-chest catheter irrigation has been the treatment of choice for a long time, with a mortality rate ranging from $4.8 \%$ to $10.8 \%{ }^{(9)}$. The unsatisfactory results of closed irrigation revived interest in a number of plastic 
Table 1. Demographic variables and per-operative data

\begin{tabular}{|c|c|c|c|}
\hline Variables & Group A $(n=22)$ & Group B $(n=19)$ & p \\
\hline Age, years, mean $\pm S D$ & $56.7 \pm 10.5$ & $57.5 \pm 11.8$ & $0.95^{*}$ \\
\hline \multicolumn{4}{|l|}{ Gender } \\
\hline Male, n (\%) & $9(40.9)$ & $7(36.8)$ & $0.79^{* *}$ \\
\hline Female, n (\%) & $13(59.1)$ & $12(63.1)$ & \\
\hline EuroSCORE & 3.8 & 3.5 & $0.86^{*}$ \\
\hline Ejection fraction, \% & $46.1 \pm 8.6$ & $48.8 \pm 9.8$ & $0.93^{*}$ \\
\hline \multicolumn{4}{|l|}{ Surgical procedures } \\
\hline CABG, n (\%) & $14(63.6)$ & $13(68.4)$ & $0.74^{\star *}$ \\
\hline Valve surgery, $\mathrm{n}(\%)$ & $8(36.4)$ & $6(31.6)$ & \\
\hline Diabetes, n (\%) & $3(13.6)$ & $4(21.1)$ & $0.68^{* \star *}$ \\
\hline Chronic renal failure, $\mathrm{n}(\%)$ & $5(22.7)$ & $6(31.6)$ & $0.52^{* *}$ \\
\hline Re-operation for bleeding, $\mathrm{n}(\%)$ & $2(9.1)$ & $3(15.8)$ & $0.64^{\star \star *}$ \\
\hline
\end{tabular}

\section{Table 2. Outcomes}

\begin{tabular}{|c|c|c|c|}
\hline Parameters & Group A $(n=22)$ & Group B $(n=19)$ & p \\
\hline Hospital death, n (\%) & 0 & $3(15.8)$ & $0.09^{*}$ \\
\hline Number of surgical debridements, median & 1.3 & 2.1 & $0.92^{\star *}$ \\
\hline Mean hospital stay, mean \pm SD & $32.2 \pm 11.3$ & $49.2 \pm 19.3$ & $0.031^{* *}$ \\
\hline Healing time, mean \pm SD & $11.9 \pm 3.1$ & $28.2 \pm 15.2$ & $<0.001^{*}$ \\
\hline Recurrent DSWI, n (\%) & 0 & $7(36.8)$ & \\
\hline Normal WBC count 7 days after debridement, $n$ & 22 & 13 & $0.066^{*}$ \\
\hline Absence of fever 7 days after debridement, $n$ & 21 & 15 & $0.164^{*}$ \\
\hline
\end{tabular}

procedures as an alternative, and in 1980, Jurkiewicz and colleagues reported the primary use of a pectoralis muscle flap $^{(2)}$. In the 1980 s and 1990 s, several studies compared closed-chest irrigation with reconstructive procedures for the treatment of mediastinitis, with no clear evidence of improved results. In 1985, Trouillet and colleagues described the use of granulated sugar for treatment of mediastinitis after cardiac surgery ${ }^{(10)}$. A new era started in 1997 when Argenta and Morykwas introduced the VAC technique, based on the application of negative pressure to wounds ${ }^{(4)}$. In 1999, Obdeijn applied VAC in the treatment of post-sternotomy mediastinitis ${ }^{(8)}$. The technique has shown excellent results in terms of definitive recovery from infection and shorter healing times than the classic treatment $^{(4-11)}$.
Mechanisms responsible for the effectiveness of VAC have been partially identified. Recently, Wackenfors and colleagues demonstrated a correlation between intensity of negative pressure and blood flow at the microvascular level in an experimental study in pigs ${ }^{(12)}$. They identified the range of -75 to $-100 \mathrm{mmHg}$ to be optimal for a maximal increase in blood flow in the muscular microvasculature around the wound. Uniform negative pressure applied to the wound leads to arteriolar dilatation and thus increases microcirculation, thereby optimizing thewound environment. By continuous suction, fluid excess and tissue edema are decreased, leading to reduced bacterial colonization. These positive effects on the wound promote granulation, tissue proliferation, and accelerated healing. Therefore, VAC technique can be accomplished safely 
and earlier than previous methods. Furthermore, VAC technique decreases the risk of complications and reduces hospital stay and costs.

The treatment of deep sternal wound infection has undergone several changes in the last 30 years. In our earlier experience, we adopted an aggressive treatment protocol, emphasizing timely debridement to prevent the infection spreading within the mediastinal space, allowing better clinical results than the previous conservative approach $^{(13-15)}$. In 2006, we reported a comparative analysis of 19 patients operated between 1999 and 2006, and another 22 patients who underwent surgeries between 2006 and 2010, developing DSWI. In the first group, an initial attempt at conservative antibiotic therapy was the rule, followed by surgical treatment in case of failure, whereas in the second group, the treatment was staged in three phases: wound debridement, removal of wires and sutures, and closed irrigation for 10 days. In case of failure, open dressing with sugar and hyperbaric therapy were applied; delayed healing and negative wound cultures mandated plastic reconstruction. This study showed that an aggressive therapeutic protocol can significantly reduce the morbidity and mortality for deep sternal wound infection. After this evidence, we applied the same aggressive approach to the use of negative pressure, obtaining a further improvement in results, as described in this study.

\section{Conclusion}

The VAC system has shown excellent results in deep sternal wound infection, with a better rate of healing and shorter hospital stay than the classic treatment based on closed-chest irrigation. This approach has also afforded satisfactory results in terms of time and rate of healing as well as survival for complex wound infection.

\section{CONFLICT Of INTEREST}

None declared.

\section{REFERENCES}

1. Shumacker HB Jr, Mandelbaum I. Continuous antibiotic irrigation in the treatment of infection. Arch Surg 1963;86:384-7.

2. Jurkiewicz MJ, Bostwick J, Hester TR, Bishop JB, Craver J. Infected median sternotomy wound: succesful treatment by muscle flaps. Ann Surg 1980;191:738-44.

3. Domkowski PW, Smith ML, Gonyon DL, et al. Evaluation of vacuum assisted closure in the treatment of post-sternotomy mediastinitis. J Thorac Surg 2003;126:386-90.

4. Morykwas MJ, Argenta LC, Shelton-Brown El, Mcguirt W. Vacuum assisted closure. A new method for wound control and treatment: animal studies and basic foundations. Ann Plast Surg 1997;38:553-62.

5. The Parisian Mediastinitis Study Group. Risk factors for deep sternal wound infection after sternotomy: a prospective, multicenter study. J Thorac Cardiovasc Surg 1996;111:1200-7.

6. Sakamato H, Fukuda I, Oosaka M, Nakata H. Risk factors and treatment of deep sterna wound infection after cardiac operation. Ann Thorac Cardiovasc Surg 2003;9:226-32.

7. Serry C, Bleck PC, Javid H, Hunter JA, Goldin MD, DeLaria GA, et al. Sternal wound complications. Management and results. $J$ Thorac Cardiovasc Surg 1980;80:861-7.

8. Obdeijn MC, de Lange MY, Lichtendahl DH, de Boer WJ. Vacuum assisted closure in the treatment of post-sternotomy mediastinitis. Ann ThoracSurg 1999;68:2358-60.

9. De Feo M, Renzulli A, Ismeno G, Gregorio R, Della Corte A, Utili $R$, et al. Variables predicting adverse outcome in patients with deep sternal wound infection. Ann Thorac Surg 2001;71:324-31.

10. Trouillet JL, Chastre J, Fagon JY, Pierre J, Domart Y, Gibert C. Use of granulated sugar in treatment of open mediastinitis after cardiac surgery. Lancet 1985;2:180-4.

11. Argenta LC, Morykwas MJ. Vacuum-assisted closure: a new method for wound control and treatment: clinical experience. Ann Plast Surg 1997;38:563-77.

12. Wackenfors A, Gustafsson R, Sjögren J, Algotsson L, Ingemansson R, Malmsjo M. Blood flow responses in the peristernal thoracic wall during vacuum-assisted closure therapy. Ann Thorac Surg 2005;79:1724-31.

13. Sjogren J, Gustafsson R, Nilsson J, Malmsjo M, Ingemansson $R$. Clinical outcome after post-sternotomy mediastinitis: vacuumassisted closure versus conventional treatment. Ann Thorac Surg 2005;79:2049-55.

14. Mohan SS, McDermott BP, Cunha BA. Methicillin-resistant Staphylococcus aureus prosthetic aortic valve endocarditis with paravalvular abscess treated with daptomycin. Heart Lung 2005;34:69-71.

15. O'Connor J, Kells A, Henry S, Scalea T. Vacuum-assisted closure for the treatment of complex chest wounds. Ann Thorac Surg 2005;79:1196-200. 